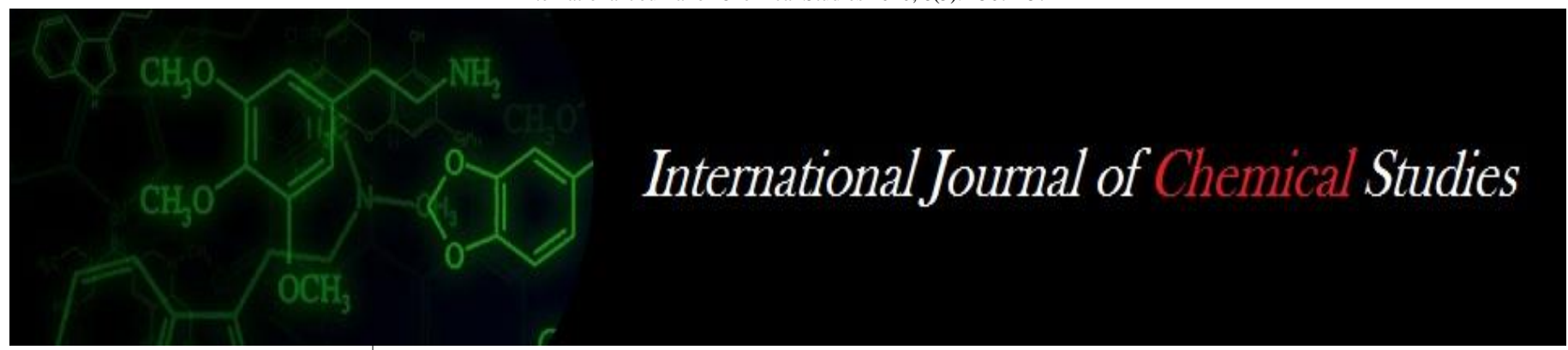

P-ISSN: 2349-8528

E-ISSN: 2321-4902

www.chemijournal.com

IJCS 2020; 8(5): 1567-1572

(C) 2020 IJCS

Received: 13-07-2020

Accepted: 07-06-2020

Aisha Majeed

College of Agriculture, Vellayani,

Thiruvananthapuram, Kerala,

India

\section{Ameena M}

College of Agriculture, Vellayani, Thiruvananthapuram, Kerala,

India

\section{Sheeba RI}

College of Agriculture, Vellayani, Thiruvananthapuram, Kerala, India
Corresponding Author:

Aisha Majeed

College of Agriculture, Vellayani,

Thiruvananthapuram, Kerala,

India

\section{Standardisation of growth media and organic nutrient schedule for container cultivation of spinach Beet (Beta vulgaris var. bengalensis)}

\author{
Aisha Majeed, Ameena M, and Sheeba RI
}

DOI: https://doi.org/10.22271/chemi.2020.v8.i5v.10519

\begin{abstract}
The treatments consisted of five growth media $\mathrm{M}_{1-}$ soil: sand: Farm yard manure (1:1:1), $\mathbf{M}_{2}$ - soil: rockdust: FYM (1:1:1), $\mathrm{M}_{3}$ - soil: compressed coirpith: FYM (1:1:1), $\mathrm{M}_{4}$ - soil: rockdust: compressed coirpith: FYM (1:0.5:0.5:1) and $\mathrm{M}_{5}$ - soil: suchitha :FYM(1:1:1) and nutrient levels were $\mathrm{N}_{1}-100 \%$ of 80:40:80 kg NPK ha ${ }^{-1}, \mathrm{~N}_{2}-\mathrm{N}_{1}+50 \% \mathrm{~N}$ top dressed in three splits, $\mathrm{N}_{3}-\mathrm{N}_{1}+100 \% \mathrm{~N}$ top dressed in three splits. M5 registered superior values for leaf yield per harvest, leaf area index and the number of leaves harvested per plant was superior in $\mathrm{M}_{2}$ and was on par with $\mathrm{M}_{5}$ and $\mathrm{M}_{1} . \mathrm{N}_{1}$ recorded the highest number of leaves harvested per plant, Leaf Area Index. The interaction $m_{5} n_{1}$ was found significantly superior with respect to leaf yield per harvest and LAI. For leaf yield per plant, $\mathrm{m}_{5} \mathrm{n}_{1}$ recorded higher value and was on par with $\mathrm{m}_{2} \mathrm{n}_{1}$. Hence the growth media $\mathrm{M}_{5}$ and organic nutrient schedule $\mathrm{N}_{1}$ can be suggested for obtaining higher yield.
\end{abstract}

Keywords: Coir pith compost, container/growbag cultivation, growth media, organic nutrient scheduling, rock dust, spinach beet, suchitha, urban farming

\section{Introduction}

Urban homesteads are a significant component of urban agriculture. Increased demographic pressure on available land and labour shortage are a common problem in the states like Kerala. We are dependent too much on the neighbouring states for many of the vegetables which are flooded with several hazardous chemicals used right from planting to storage. This has created an awareness among urban population and led them to the habit of cultivating their own food within the home premises. Growing their own food within home means getting it fresh, unspoiled, perfectly ripened at fingertips, reduced transport and creating a bio- diversity in the garden. Leafy vegetables has a major role in human diet. According to Indian Council of Medical Research (2013) ${ }^{[9]}$, the recommended dietary allowance of leafy vegetable for an adult person is $125 \mathrm{~g}$ per day. Among the leafy vegetables, spinach beet (Beta vulgaris var. bengalensis), the most popular leafy vegetable in north India is a new introduction to Kerala. It is cultivated throughout the plains of north India during winter season. Spinach beet is particularly valued for its high ascorbic acid $(40.9 \mathrm{mg})$, calcium $(73 \mathrm{mg})$, iron $(4.8 \mathrm{mg})$ and riboflavin $(0.26 \mathrm{mg})$ content. It is regarded as the richest source of vitamin A amongst all the vegetables.

The potting media usually used for container cultivation is soil, sand and farmyard manure in the ratio 1: 1: 1. Non-availability of sand and its high cost necessitates the introduction of alternate components for growth media preparation. Rock dust may be co-utilised with compost in soil and horticultural growing media or alternatively may be a feedstock to a composting process (Szmidt et al., 1997) ${ }^{[16]}$. Coir pith improves soil conditions like drainage and stimulates growth of most of the crops when used as rooting media. Application of coir pith in soil helps in improving the structure and other physical and chemical properties of the soil (Bopaiah, 1991) ${ }^{[3]}$. In this context, the possibility of utilising coir pith and rockdust which is available in plenty and cheap as a substitute for sand need to be investigated for its suitability to spinach beet cultivation. 'Suchitha', is a patented eco-friendly product developed by Department of Soil Science and Agricultural Chemistry, College of Agriculture, Vellayani by thermochemical digestion of degradable waste. 
The suitability of using this product as a growth medium component is also envisaged in this study.

Spinach beet responds well to applied nutrients. At present, there is a lack of separate nutrient recommendation for spinach beet grown organically in containers. The NPK recommendation for spinach beet is $80: 40: 80 \mathrm{~kg} \mathrm{ha}^{-1}$ (Alur, $2017)^{[1]}$. As people prefer organically grown vegetables over inorganic vegetables in home gardens it is necessary to standardize an organic nutrient schedule for container grown vegetables. In this context, an experiment was conducted to standardize the potting media and nutrient scheduling for container grown spinach beet.

\section{Materials and Methods}

The experiment was conducted at the Instructional Farm attached to College of Agriculture, Vellayani, Kerala, which is located at $8^{\circ} 25^{\prime} 45.977^{\prime \prime} \mathrm{N}$ latitude and $76^{\circ} 59^{\prime} 22.123$ " $\mathrm{E}$ longitude from October 2019 to February 2020. The region enjoys a humid tropical climate experiencing a temperature of 22.3 to $32.7^{\circ} \mathrm{C}$ and relative humidity of $94.4 \%$. A total of $125.46 \mathrm{~mm}$ rainfall has been received in 105 days during the cropping period. The variety used was All Green. The treatments consisted of five growth media $\mathbf{M}_{1-}$ soil: sand: FYM (1:1:1), $\mathbf{M}_{2}$ - soil: rockdust: FYM (1:1:1), $\mathbf{M}_{3}$ - soil: compressed coirpith: FYM (1:1:1), $\mathbf{M}_{4}$ - soil: rockdust: compressed coirpith: FYM (1:0.5:0.5:1) and $\mathrm{M}_{5}$ - soil: suchitha :FYM(1:1:1) with three levels of nutrient $\mathrm{N}_{1}-100 \%$ of 80:40:80 kg NPK ha ${ }^{-1}, \mathrm{~N}_{2}-\mathrm{N}_{1}+50 \% \mathrm{~N}$ top dressed in three splits, $\mathrm{N}_{3}-\mathrm{N}_{1}+100 \% \mathrm{~N}$ top dressed in three splits. The NPK recommendation for spinach beet is 80:40: $80 \mathrm{~kg} \mathrm{ha}^{-1}$ (Alur, 2017) ${ }^{[1]}$ and nutrient requirement calculated on the basis of plant population. Poultry manure $(1.6 \% \mathrm{~N}, 0.983 \%$ $\mathrm{P}_{2} \mathrm{O}_{5}$ and $\left.1.84 \% \mathrm{~K}_{2} \mathrm{O}\right)$ and fermented groundnut cake $(2 \% \mathrm{~N})$, were used as nutrient sources for $\mathrm{N}, \mathrm{P}$ and $\mathrm{K}$ respectively and applied as per the nutrient levels. Neem cake @ $5 \mathrm{~g} \mathrm{growbag}^{-1}$ was applied uniformly to all the growbags before sowing.
The experiment was laid out as $5 \times 3$ factorial experiment with three replications in completely randomized design. The experimental site was cleared and black polythene mulch sheet was spread on the site. UV stabilized woven plastic sacks of thickness 1400 denier capable of holding $15 \mathrm{~kg}$ potting mixture was used as the container. Uniform quantity of potting media was taken in each growbag. The growbags were placed at a spacing of $20 \mathrm{~cm}$ between rows and $10 \mathrm{~cm}$ between plants. The weeds were removed from the growbags by hand weeding, as and when they appeared and the plants were irrigated uniformly. Harvesting commenced from 60 DAS. Subsequent harvests of matured leaves were taken at 15 days interval. Growth and yield attributes were recorded and data was analysed statistically.

\section{Results and Discussion \\ (a) Growth media standardization for container grown spinach beet}

The study revealed that the various growth media tested had a significant influence on growth and yield characters of container grown spinach beet. Results of the study revealed that the growth media tested had significant influence on plant height at all stages except at 90 DAS (Table 1). Up to 60 DAS, growth media with sand replaced by rock dust and compressed coir pith (CCP) together in equal proportion recorded taller plants. However, from 105 DAS onwards, growth medium with suchitha as substitute for sand recorded taller plants. Hale and Orcutt (1987) ${ }^{[8]}$ reported increase in plant height in the medium containing compressed coirpith which he attributed to the presence of higher form of nitrogen at higher quantities leading to increase in vegetative growth of plants mainly by cell elongation and partly by cell division. Along with coirpith, rockdust also contributed as a media component by way of remineralisation. Fragstein and Vogtmann (1987) ${ }^{[6]}$ reported that rockdust contains most of the nutrients required for plant growth except $\mathrm{N}$ and $\mathrm{P}$. The favourable effects of these two media components together

Table 1: Effect of growth media and nutrient levels on plant height and leaf area index of spinach beet at different growth stages

\begin{tabular}{|c|c|c|c|c|c|c|c|c|c|c|c|}
\hline \multirow[b]{2}{*}{ Treatments } & \multicolumn{6}{|c|}{ Plant height } & \multicolumn{5}{|c|}{ Leaf area index } \\
\hline & $\begin{array}{c}\text { 30 } \\
\text { DAS }\end{array}$ & $\begin{array}{c}\text { 60 } \\
\text { DAS }\end{array}$ & $\begin{array}{c}75 \\
\text { DAS }\end{array}$ & $\begin{array}{c}90 \\
\text { DAS }\end{array}$ & $\begin{array}{l}105 \\
\text { DAS }\end{array}$ & $\begin{array}{l}120 \\
\text { DAS }\end{array}$ & $\begin{array}{c}\text { 60 } \\
\text { DAS }\end{array}$ & $\begin{array}{l}75 \\
\text { DAS }\end{array}$ & $\begin{array}{c}90 \\
\text { DAS }\end{array}$ & $\begin{array}{c}105 \\
\text { DAS }\end{array}$ & $\begin{array}{l}120 \\
\text { DAS }\end{array}$ \\
\hline \multicolumn{12}{|c|}{ Growth media $(\mathbf{M})$} \\
\hline $\mathrm{M}_{1 \text { (soil: sand: FYM in } 1: 1: 1)}$ & 24.03 & 26.55 & 29.29 & 34.87 & 32.44 & 1.24 & 0.70 & 0.80 & 0.74 & 0.71 & 0.7 \\
\hline $\mathrm{M}_{2}$ (soil: rockdust: $\mathrm{FYM}$ in $1: 1: 1$ ) & 27.63 & 30.67 & 33.24 & 33.27 & 35.99 & 1.32 & 0.75 & 0.82 & 0.76 & 0.73 & 0.71 \\
\hline $\mathrm{M}_{3}$ (soil: compressed coirpith: FYM in 1:1:1) & 26.07 & 31.99 & 30.83 & 35.11 & 34.74 & 1.16 & 0.66 & 0.79 & 0.77 & 0.76 & 0.74 \\
\hline $\begin{array}{c}\mathrm{M}_{4} \text { (soil: rockdust: compressed coirpith: FYM in } \\
1: 0.5: 0.5: 1)\end{array}$ & 29.96 & 32.66 & 32.85 & 35.07 & 27.59 & 1.43 & 0.81 & 0.83 & 0.79 & 0.78 & 0.77 \\
\hline M5 (soil: suchitha: FYM in 1:1:1) & 21.52 & 31.33 & 32.94 & 33.59 & 38.26 & 1.51 & 0.85 & 1.17 & 1.11 & 1.02 & 0.98 \\
\hline SEm $( \pm)$ & 0.86 & 0.65 & 0.77 & 0.63 & 1.82 & 0.01 & 0.008 & 0.006 & 0.007 & 0.007 & 0.009 \\
\hline $\mathrm{CD}(0.05)$ & 2.502 & 1.903 & 2.232 & NS & 5.276 & 0.043 & 0.024 & 0.018 & 0.02 & 0.021 & 0.025 \\
\hline \multicolumn{12}{|c|}{ Nutrient levels $(\mathbf{N})$} \\
\hline $\mathrm{N}_{1}\left(100 \%\right.$ of $\left.80: 40: 80 \mathrm{~kg}^{2} \mathrm{NK} \mathrm{ha}^{-1}\right)$ & 25.77 & 30.76 & 31.76 & 34.34 & 30.82 & 1.36 & 0.77 & 0.92 & 0.88 & 0.83 & 0.81 \\
\hline $\mathrm{N}_{2}(\mathrm{~N} 1+50 \% \mathrm{~N}$ topdressed in 3splits) & 24.46 & 30.22 & 30.24 & 33.59 & 34.93 & 1.38 & 0.78 & 0.87 & 0.81 & 0.79 & 0.77 \\
\hline $\mathrm{N}_{3}(\mathrm{~N} 1+100 \% \mathrm{~N}$ topdressed in 3splits) & 27.29 & 31.06 & 33.48 & 34.85 & 35.66 & 1.26 & 0.71 & 0.85 & 0.81 & 0.78 & 0.76 \\
\hline $\operatorname{SEm}( \pm)$ & 0.67 & 0.51 & 0.60 & 0.49 & 1.41 & 0.011 & 0.006 & 0.005 & 0.005 & 0.006 & 0.007 \\
\hline $\mathrm{CD}(0.05)$ & 1.938 & NS & 1.729 & NS & 4.087 & 0.033 & 0.019 & 0.014 & 0.015 & 0.016 & 0.02 \\
\hline
\end{tabular}

Table 2: Effect of growth media and nutrient levels on leaf yield per harvest, no. of leaves harvested per plant and leaf yield per plant

\begin{tabular}{|c|c|c|c|c|c|c|c|}
\hline \multirow[b]{2}{*}{ Treatments } & \multicolumn{5}{|c|}{ Leaf yield per harvest (g) } & \multirow[b]{2}{*}{$\begin{array}{c}\text { No. of leaves harvested per } \\
\text { plant }\end{array}$} & \multirow{2}{*}{$\begin{array}{c}\text { Leaf yield per } \\
\text { plant } \\
\text { (g per plant) }\end{array}$} \\
\hline & $\begin{array}{c}\mathbf{6 0} \\
\text { DAS }\end{array}$ & $\begin{array}{c}75 \\
\text { DAS }\end{array}$ & $\begin{array}{c}90 \\
\text { DAS }\end{array}$ & $\begin{array}{c}105 \\
\text { DAS }\end{array}$ & $\begin{array}{c}120 \\
\text { DAS }\end{array}$ & & \\
\hline \multicolumn{8}{|c|}{ Growth media (M) } \\
\hline $\mathrm{M}_{1}$ (soil: sand: FYM $(1: 1: 1)$ & 13.84 & 22.64 & 19.20 & 16.10 & 15.17 & 22.97 & 86.78 \\
\hline $\mathrm{M}_{2}$ (soil: rockdust: FYM $(1: 1: 1)$ & 18.33 & 32.38 & 31.51 & 19.68 & 17.31 & 24.54 & 99.68 \\
\hline $\mathrm{M}_{3}$ (soil: compressed coirpith: FYM $(1: 1: 1)$ & 10.41 & 20.73 & 15.33 & 16.34 & 15.15 & 19.98 & 77.98 \\
\hline
\end{tabular}




\begin{tabular}{|c|c|c|c|c|c|c|c|}
\hline $\begin{array}{l}\mathrm{M}_{4} \text { (soil: rockdust: compressed coirpith: FYM } \\
(1: 0.5: 0.5: 1)\end{array}$ & 15.62 & 26.32 & 20.24 & 15.40 & 14.74 & 21.57 & 90.38 \\
\hline $\mathrm{M}_{5}$ (soil: suchitha: FYM $(1: 1: 1)$ & 22.85 & 32.67 & 24.67 & 20.67 & 18.92 & 24.28 & 118.08 \\
\hline SEm $( \pm)$ & 0.80 & 1.48 & 10.15 & 0.95 & 0.84 & 0.94 & 3.62 \\
\hline $\mathrm{CD}(0.05)$ & 2.328 & 4.321 & NS & 2.767 & 2.450 & 2.739 & 10.512 \\
\hline \multicolumn{8}{|c|}{ Nutrient levels $(\mathbf{N})$} \\
\hline $\mathrm{N}_{1}\left(100 \%\right.$ of $\left.80: 40: 80 \mathrm{~kg} \mathrm{NPK} \mathrm{ha}^{-1}\right)$ & 16.41 & 28.65 & 33.08 & 18.53 & 16.66 & 23.29 & 97.88 \\
\hline $\mathrm{N}_{2}\left(\mathrm{~N}_{1}+50 \% \mathrm{~N}\right.$ topdressed in 3splits) & 15.96 & 25.68 & 20.28 & 16.99 & 16.26 & 20.87 & 93.51 \\
\hline $\mathrm{N}_{3}$ (N1+100\% N topdressed in 3splits) & 16.26 & 26.52 & 19.21 & 17.39 & 15.86 & 23.84 & 91.58 \\
\hline $\operatorname{SEm}( \pm)$ & 0.62 & 1.15 & 7.86 & 0.73 & 0.65 & 0.73 & 2.81 \\
\hline $\mathrm{CD}(0.05)$ & NS & NS & NS & NS & NS & 2.121 & NS \\
\hline
\end{tabular}

might have contributed to production of taller plants during initial stage. The effect of suchitha was visible during later period of crop growth and it may be due to the availability of nutrients at later stages of crop growth. It was reported that the application of rapid organic fertilizer (suchitha) has resulted an increase in the availability of micronutrients at the later stages of banana crop (Leno and Sudharmaidevi, 2018) ${ }^{[11]}$. Leaf area shows the photosynthetic efficiency of plants and so does the leaf area index (LAI). LAI was higher for the growth medium $\mathrm{M}_{5}$ at all the growth stages and it was significantly superior over all other treatments(Table 1). This could be ascribed to the higher initial NPK status of the growth medium $\mathrm{M}_{5}$ compared to others. Gairola et.al (2009) ${ }^{[7]}$ reported higher LAI in spinach beet in treatments where $\mathrm{K}$ was applied along with $\mathrm{N}$ and $\mathrm{P}$ than treatments where no $\mathrm{K}$ was applied. The higher LAI automatically augment solar energy harvesting ability and as a result there is enhancement in the production of photosynthates and their subsequent translocation and hence total dry matter production. It is apparent from the data that higher LAI would increase the leaf yield in the growth medium $\mathrm{M}_{5}$. Though growth medium $\mathrm{M}_{3}$ recorded a comparable initial NPK status to $\mathrm{M}_{5}$, the growth medium combination could not support a better crop growth.
Coirpith possess a high-water retention capacity of 600-800 per cent and a maximum of 1100 per cent (Coir Board, 2016) [4]. However, the high-water holding capacity of cocopeat causes poor air-water relationship which will lead to low aeration within the medium thus affecting the oxygen diffusion to the roots. This might have caused reduction in the yield of spinach beet in the growth medium $\mathrm{M}_{3}$ even though it had high initial $\mathrm{K}$ and $\mathrm{N}$ status.

The major yield attributes studied were leaf yield per harvest, no. of leaves harvested per plant and leaf yield per plant. Most of the yield determining factors studied were found superior in the growth medium $\mathrm{M}_{5}$. Though the number of leaves harvested per plant was higher for the growth medium $\mathbf{M}_{2}$, it was on par with $\mathrm{M}_{5}$. This might be due to the higher availability of nutrients and growth substances throughout the growth period. Jayakrishna et al. (2016) ${ }^{[10]}$ reported that the yield of chilli was higher for the growth medium with soil, coirpith compost and suchitha in the ratio 1:2:1. Yield enhancement by rockdust application had been illustrated by Rose (2008) ${ }^{[5]}$ in coleus where highest number of tubers per plant and total dry matter application with rock dust applied @ $10 \mathrm{t} \mathrm{ha}^{1}$ along with equal quantity of FYM and 50 percent of chemical fertilizers.

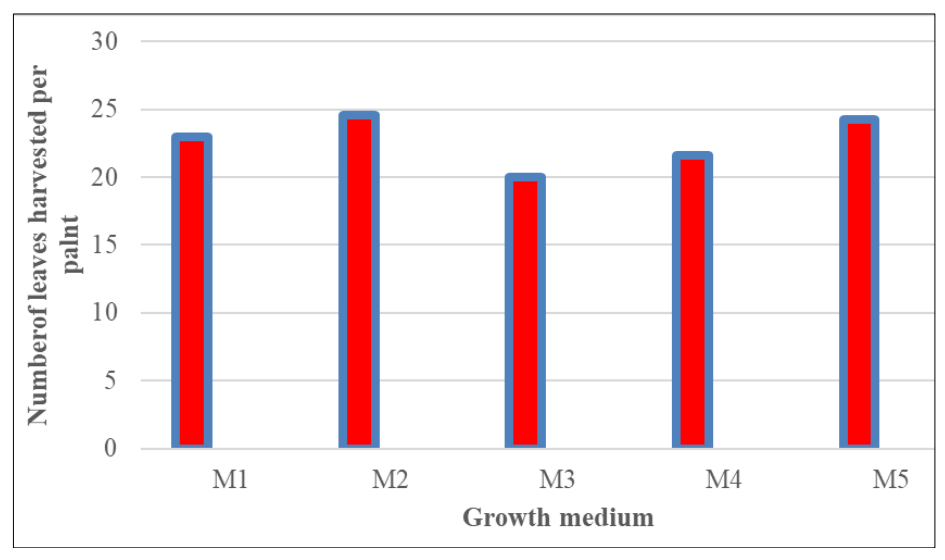

Fig 1: Effect of growth medium on leaf yield per plant in spinach beet

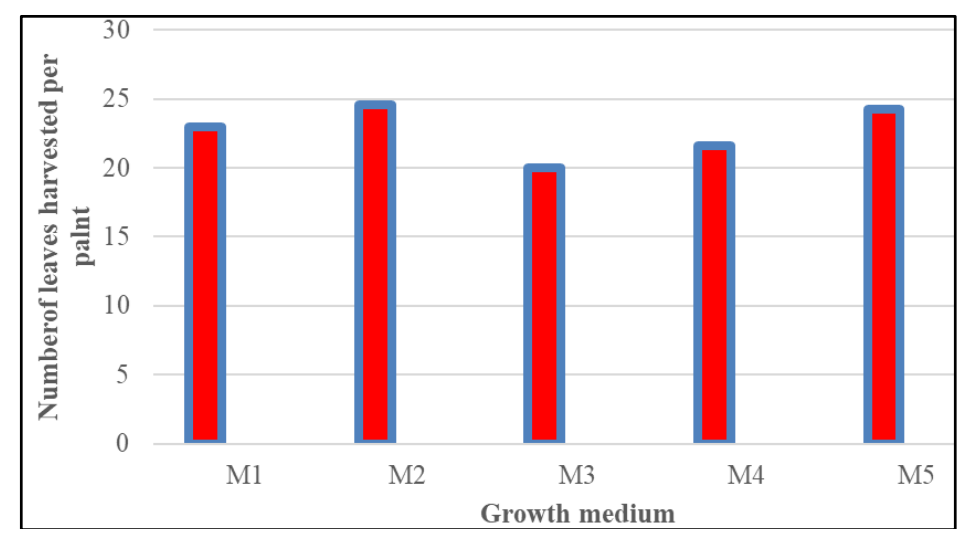

Fig 2: Effect of growth medium on number of leaves harvested per plant in spinach beet 
Even though number of leaves per plant was higher for the growth medium $\mathbf{M}_{2}, \mathrm{M}_{5}$ and $\mathrm{M}_{1}$, the leaf yield per plant was significantly superior for growth medium $\mathrm{M}_{5}$ (Table 2). This might be due to the large thick leaves produced in the medium comprising of suchitha. Taller plants and higher LAI also contributed to a higher leaf weight and this could be due to the higher nutrient availability with the presence of suchitha. This pointed to the fact that there might not be any positive correlation between number of leaves harvested and the leaf yield per plant in spinach beet. This is in consonance with the findings of Raghunath (2001) [14] where no positive correlation between yield and number of leaves was reported. Since suchitha is made from organic food wastes, its rich nutritional status for both micro and macro nutrients would be the probable reason for higher nutrient availability in $\mathbf{M}_{5}$. Jayakrishna et al. (2016) ${ }^{[10]}$ reported nutritional status of suchitha as $3.6 \% \mathrm{~N}, 0.4 \% \mathrm{P}, 1.5 \% \mathrm{~K}$ and micronutrients as $\mathrm{Fe}\left(3518 \mathrm{mg} \mathrm{kg}^{-1}\right), \mathrm{Mn}\left(172 \mathrm{mg} \mathrm{kg}^{-1}\right), \mathrm{Cu}\left(52 \mathrm{mg} \mathrm{kg}^{-1}\right), \mathrm{Zn}$ (197 $\mathrm{mg} \mathrm{kg}^{-1}$ ) and $\mathrm{B}\left(1.2 \mathrm{mg} \mathrm{kg}^{-1}\right)$. Nitrogen, being a component of protoplasm had a favourable effect on chlorophyll content of leaves and resulted in increased synthesis of carbohydrates.

\section{(b) Nutrient scheduling for container grown Spinach beet}

Nutrient management especially nitrogen has a significant importance in spinach beet as leaves are the economically important plant part. Rajeswari and Shakila (2009) [13] reported organic nutrition to be the best for spinach beet. However, there is a lack of an organic nutrient schedule for container grown spinach beet at present. The present recommended dose (RD) of NPK for the crop is 80:40:80 kg per ha (Alur, 2017) ${ }^{[1]}$. As organic manures serve as slow release source of $\mathrm{N}, \mathrm{P}$ and $\mathrm{K}$ for plant nutrition and microbial growth, higher doses of nitrogen (150 and 200 per cent) in addition to the RD of NPK were tested for formulating an organic nutrient schedule.

The results of the study revealed that plants fertilised with RD of NPK through organic sources recorded superior values with respect to height, LAI and no of leaves harvested per plant. This imply the fact that higher dose of nitrogen via organic sources could not bring about any substantial increase in plant height or no of leaves per plant. Correspondingly, nutrient levels could not produce any significant influence on leaf yield per harvest and leaf yield per plant. Manure application at RD might have provided the required NPK for plant growth. In spinach, Magen (2008) ${ }^{[12]}$ reported balanced NPK nutrition for increased yield.

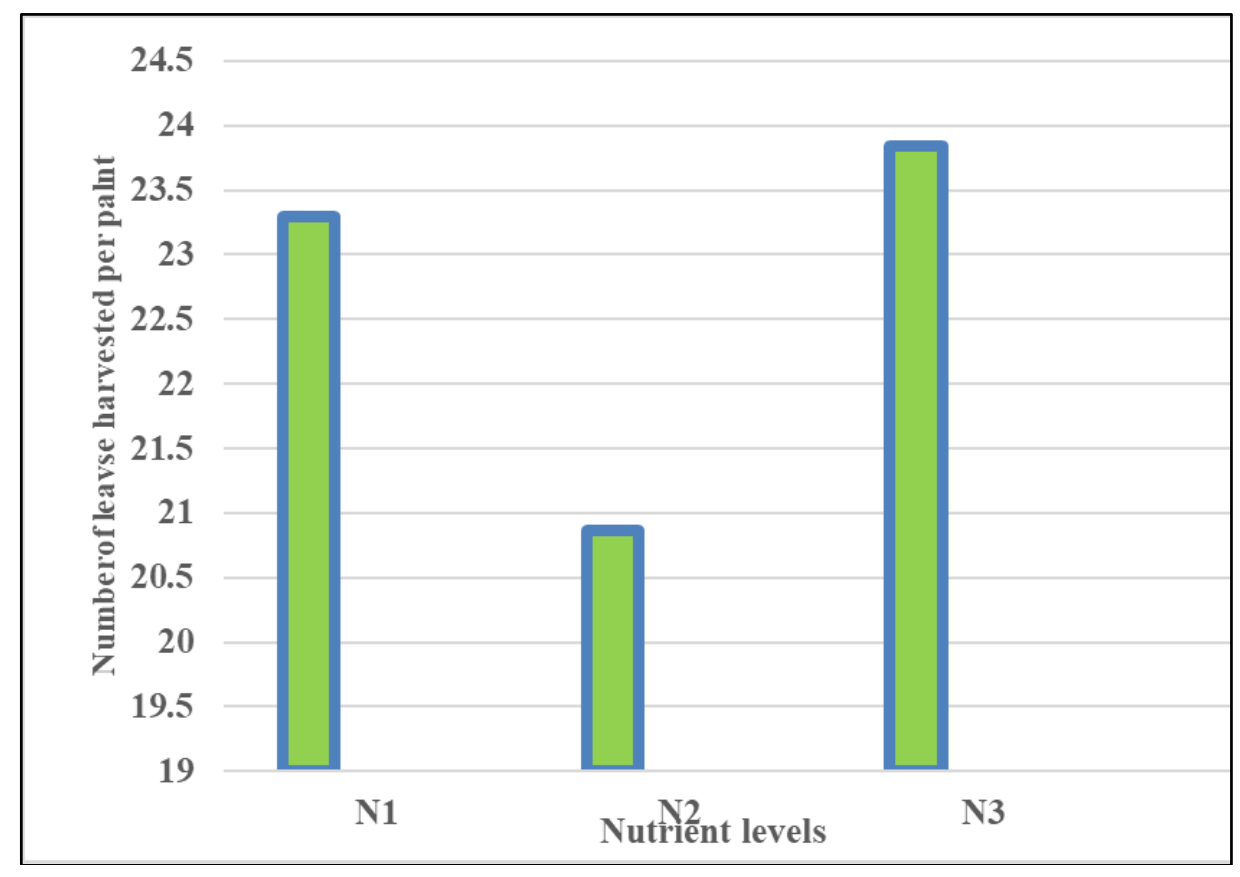

Fig 3: Effect of nutrient levels on number of leaves harvested per plant in spinach

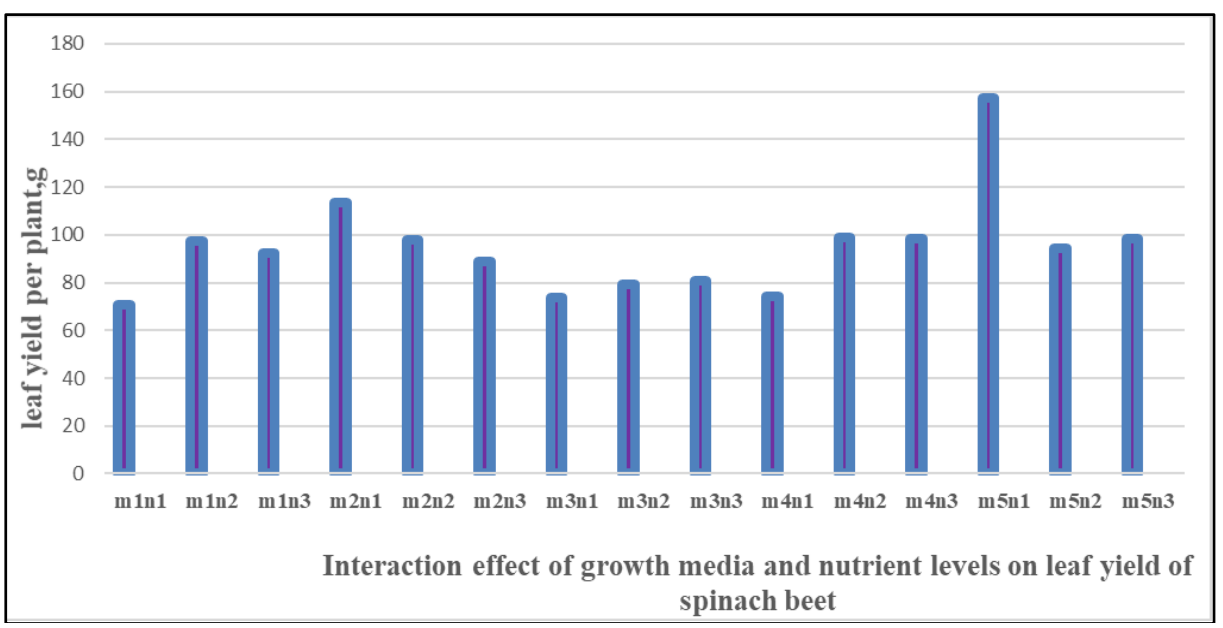

Fig 4: Interaction effect of growth medium and nutrient levels on leaf yield per plant in spinach beet $\sim 1570 \sim$ 
Table 3: Interaction effect of growth media and nutrient levels on plant height and leaf area index of spinach beet at different growth stages

\begin{tabular}{|c|c|c|c|c|c|c|c|c|c|c|c|}
\hline \multirow{2}{*}{ Treatment combination $(\mathrm{M} \times \mathrm{N})$} & \multicolumn{6}{|c|}{ Plant height $(\mathrm{cm})$} & \multicolumn{5}{|c|}{ Leaf area index } \\
\hline & 30 DAS & $60 \mathrm{DAS}$ & 75 DAS & 90 DAS & 105 DAS & 120 DAS & 60 DAS & 75 DAS & 90 DAS & 105 DAS & 120 DAS \\
\hline $\mathrm{m}_{1} \mathrm{n}_{1}$ & 21.33 & 25.33 & 26.99 & 32.10 & 30 & 27.33 & 0.68 & 0.78 & 0.73 & 0.71 & 0.69 \\
\hline $\min _{2}$ & 24.77 & 26.77 & 27.10 & 34.11 & 33.77 & 31.88 & 0.79 & 0.85 & 0.79 & 0.77 & 0.76 \\
\hline$m_{1} n_{3}$ & 25.99 & 27.55 & 33.77 & 38.38 & 33.55 & 32.22 & 0.64 & 0.76 & 0.70 & 0.65 & 0.64 \\
\hline $\mathrm{m}_{2} \mathrm{n}_{1}$ & 26.99 & 30.38 & 33.44 & 34.16 & 37.77 & 35.10 & 0.82 & 0.87 & 0.82 & 0.77 & 0.75 \\
\hline $\mathrm{m}_{2} \mathrm{n}_{2}$ & 25.10 & 29.99 & 32.05 & 32.88 & 33.55 & 31 & 0.74 & 0.80 & 0.71 & 0.68 & 0.65 \\
\hline $\mathrm{m}_{2} \mathrm{n}_{3}$ & 30.77 & 32.22 & 34.22 & 32.77 & 36.66 & 33.77 & 0.68 & 0.8 & 0.75 & 0.73 & 0.72 \\
\hline $\mathrm{m}_{3} \mathrm{n}_{1}$ & 28.44 & 33.22 & 31.16 & 34.83 & 32.44 & 31.44 & 0.64 & 0.78 & 0.77 & 0.76 & 0.75 \\
\hline$m_{3} n_{2}$ & 25.55 & 31.55 & 31.16 & 36.49 & 35.77 & 33.22 & 0.68 & 0.84 & 0.80 & 0.79 & 0.79 \\
\hline$m_{3} n_{3}$ & 24.22 & 31.22 & 30.16 & 33.99 & 35.99 & 34.33 & 0.65 & 0.76 & 0.76 & 0.74 & 0.69 \\
\hline $\mathrm{m}_{4} \mathrm{n}_{1}$ & 29.88 & 32.44 & 31.16 & 31.99 & 32.88 & 32.33 & 0.81 & 0.82 & 0.77 & 0.76 & 0.75 \\
\hline $\mathrm{m}_{4} \mathrm{n}_{2}$ & 27.44 & 31.55 & 29.16 & 33.44 & 33.88 & 32.33 & 0.83 & 0.87 & 0.83 & 0.83 & 0.8 \\
\hline $\mathrm{m}_{4} \mathrm{n}_{3}$ & 32.55 & 33.99 & 38.22 & 39.77 & 35.22 & 36.87 & 0.8 & 0.79 & 0.78 & 0.75 & 0.75 \\
\hline $\mathrm{m}_{5} \mathrm{n}_{1}$ & 22.21 & 32.44 & 36.05 & 38.61 & 40.21 & 35.22 & 0.91 & 1.35 & 1.32 & 1.15 & 1.09 \\
\hline $\mathrm{m}_{5} \mathrm{n}_{2}$ & 19.44 & 31.22 & 31.72 & 32.83 & 37.66 & 34.33 & 0.85 & 0.99 & 0.92 & 0.87 & 0.84 \\
\hline $\mathrm{m}_{5} \mathrm{n}_{3}$ & 22.88 & 30.33 & 31.05 & 29.32 & 36.88 & 32.11 & 0.80 & 1.16 & 1.1 & 1.05 & 1.00 \\
\hline $\operatorname{SEm}( \pm)$ & 1.49 & 1.14 & 1.33 & 1.09 & 3.15 & 1.47 & 0.014 & 0.011 & 0.012 & 0.012 & 0.015 \\
\hline $\mathrm{CD}(0.05)$ & $\mathrm{NS}$ & $\mathrm{NS}$ & 3.866 & 3.179 & 9.139 & 4.267 & 0.042 & 0.032 & 0.034 & 0.036 & 0.044 \\
\hline
\end{tabular}

Table 4: Interaction effect of growth media and nutrient levels on leaf yield per harvest, no. of leaves

\begin{tabular}{|c|c|c|c|c|c|c|c|}
\hline \multirow{2}{*}{ Treatments } & \multicolumn{5}{|c|}{ Leaf yield per harvest (g) } & \multirow{2}{*}{ No. of leaves harvested per plant } & \multirow{2}{*}{$\begin{array}{l}\text { Leaf yield per plant } \\
\text { (g per plant) }\end{array}$} \\
\hline & 60 DAS & 75 DAS & 90 DAS & 105 DAS & 120 DAS & & \\
\hline \multicolumn{8}{|c|}{$\mathbf{M} \times \mathbf{N}$} \\
\hline $\mathrm{m}_{1} \mathrm{n}_{1}$ & 10.98 & 19.55 & 10.10 & 12.66 & 11.29 & 17.08 & 70.61 \\
\hline $\min _{12}$ & 16.39 & 25.11 & 24.22 & 15.88 & 16.95 & 26.34 & 97.21 \\
\hline $\mathrm{m}_{1} \mathrm{n}_{3}$ & 14.17 & 23.27 & 23.27 & 19.77 & 17.27 & 25.49 & 92.54 \\
\hline $\mathrm{m}_{2} \mathrm{n}_{1}$ & 19.16 & 38.22 & 47.33 & 24.11 & 21.66 & 28.76 & 113.72 \\
\hline $\mathrm{m}_{2} \mathrm{n}_{2}$ & 17.64 & 27.21 & 17.99 & 18.60 & 16.32 & 19.64 & 97.70 \\
\hline $\mathrm{m}_{2} \mathrm{n}_{3}$ & 18.21 & 31.72 & 19.21 & 16.33 & 13.95 & 25.20 & 88.63 \\
\hline $\mathrm{m}_{3} \mathrm{n}_{1}$ & 12.78 & 17.22 & 12.77 & 16.60 & 14.22 & 20.98 & 73.60 \\
\hline $\mathrm{m}_{3} \mathrm{n}_{2}$ & 11.39 & 23.00 & 15.00 & 14.88 & 15.07 & 18.20 & 79.34 \\
\hline$m_{3} n_{3}$ & 7.05 & 21.99 & 18.22 & 17.55 & 16.18 & 20.76 & 81.00 \\
\hline $\mathrm{m}_{4} \mathrm{n}_{1}$ & 12.15 & 26.21 & 18.86 & 11.00 & 12.33 & 20.63 & 74.00 \\
\hline $\mathrm{m}_{4} \mathrm{n}_{2}$ & 15.44 & 28.00 & 22.77 & 15.88 & 14.66 & 19.20 & 98.77 \\
\hline $\mathrm{m}_{4} \mathrm{n}_{3}$ & 19.27 & 24.77 & 19.10 & 19.33 & 17.23 & 24.87 & 98.38 \\
\hline $\mathrm{m}_{5} \mathrm{n}_{1}$ & 26.96 & 42.06 & 36.33 & 28.31 & 23.80 & 28.98 & 157.47 \\
\hline $\mathrm{m}_{5} \mathrm{n}_{2}$ & 18.96 & 25.11 & 21.44 & 19.70 & 18.30 & 20.99 & 94.55 \\
\hline
\end{tabular}

The interaction between growth medium and nutrient levels had significant influence on the growth and yield parameters of container grown spinach beet. Among the interactions, $\mathrm{m}_{5} \mathrm{n}_{1}$ had significant effect on leaf yield per harvest, leaf area index and leaf yield per plant (Table 3 and 4). This might be due to the cumulative effect of individual treatments. Anjana (2017) ${ }^{[2]}$ reported significance of interaction between growth media combinations and nutrient levels in registering higher number of primary branches per plant in container grown yardlong bean.

\section{Conclusion}

The best growth media i.e. soil: suchitha: FYM in 1: 1: 1 ratio and organic nutrient schedule of $100 \%$ recommended dose of 80:40:80 kg NPK ha ${ }^{-1}$ with entire dose as basal application for container grown spinach beet is found to produce good yield.

\section{References}

1. Alur V. Productivity of spinach beet as influenced by varieties and nutrient doses. M.Sc.(Ag) thesis, Kerala Agricultural University, Thrissur, 2017, 139.

2. Anjana S. Agro techniques for container grown yardlong bean. M.Sc.(Ag) thesis, Kerala Agricultural University, Thrissur, 2017, 153.

3. Bopaiah BM. Recycling the coconut wastes to improve the soil fertility in coconut gardens. Indian Coconut J.
1991; 22(3):2-3.

4. Coir board. Coir pith wealth from waste a reference. Ministry of Micro, Small and Medium enterprises, Govt. of India, 2016, 7- 26.

5. Rose SSR. Rock dust as a nutrient source for coleus (Solenostemon rotundifolius (Poir Morton) M.Sc. (Ag) thesis, Kerala Agricultural University, Thrissur, 2008, 69.

6. Fragstein PV, Vougtmann H. Organic extracts for the treatment of rock powder, fertilizers in biological agriculture. Biol. Agric. Hortic. 1987; 1:169-180.

7. Gairola S, Umar S, Suryapani S. Nitrate accumulation, growth and leaf quality of Spinach beet (Beta vulgaris Linn.) as affected by NPK fertilization with special reference to potassium. Indian J Sci. Technol. 2009; 2(2):237-240.

8. Hale MG, Orcutt DM. The physiology of plant under stress. A Wiley Inter Science Publications, Newyork. 1987; 71-72:145-166.

9. ICMR (Indian Council of Medical Research), Nutrient Requirements and Recommended Dietary Allowance, National Institute of Nutrition, Hyderabad, 2013.

10. Jayakrishna J, Thampatti KCM, Leno N. Standardisation of growth medium based on thermochemical digest produced from degradable solidwaste by rapid conversion technology. Int. J Appl. Pure. Sci. Agric. 2016; 2(10):76-80. 
11. Leno N, Sudharmaidevi CR. Micronutrient dynamics on addition of a rapid organic fertilizer produced from degradable waste in banana. Int. J Current Microbiol. Applied Sci. 2018; 7(1):1095-1102.

12. Magen H. Balanced crop nutrition: Fertilizing for crop and food quality. Turk J Agric. 2008; 32:183-193.

13. Rajeswari R, Shakila A. Effect of organic manures on nutrient uptake of palak (Beta vulgaris L. var. bengalensis). Asian J Hort. 20104; (2):405-407.

14. Raghunath BM. Studies on effect of sowing dates and nitrogen levels on leaf yield in Palak (Beta vulgaris L.) M.Sc. (Ag) Thesis, Vasantrao Naik Marathwada Krishi Vidyapeeth, Parbhani, 2001, 139.

15. Rose SSD. Rock dust as a nutrient source for coleus (Solenostemon rotundifolius (Poir Morton) M.Sc. (Ag) thesis, Kerala Agricultural University, Thrissur, 2008, 69.

16. Szmidt RA, Ferguson J, McLennan S, Wilkins CA. Potential for co-utilisation of rockdust and composted material. In: International Symposium on Composting and Use of Composted Material in Horticulture. 1997; 469:51-60. 